\title{
Analisis Ekspansi Gojek di Singapura Tahun 2018 Melalui Foreign Direct Investment (FDI)
}

\author{
Al Dina Maulidya ${ }^{1 *}$, Bagas Prasetyo $^{2}$, Marsha Salsabilla $^{3}$, Rizal Alif Prakasya ${ }^{4}$ \\ ${ }^{1}$ Mahasiswa Universitasi Muhammadiyah Malang, email: aldinamaulidyaa@gmail.com \\ ${ }^{2}$ Mahasiswa Universitasi Muhammadiyah Malang, email: bagasp7416@gmail.com \\ ${ }^{3}$ Mahasiswa Universitasi Muhammadiyah Malang, email: marshasalsabilla24@gmail.com \\ ${ }^{4}$ Mahasiswa Universitasi Muhammadiyah Malang, email: rizalhoprakasya@gmail.com
}

\section{ARTICLES INFORMATION}

\section{ABSTRACT}

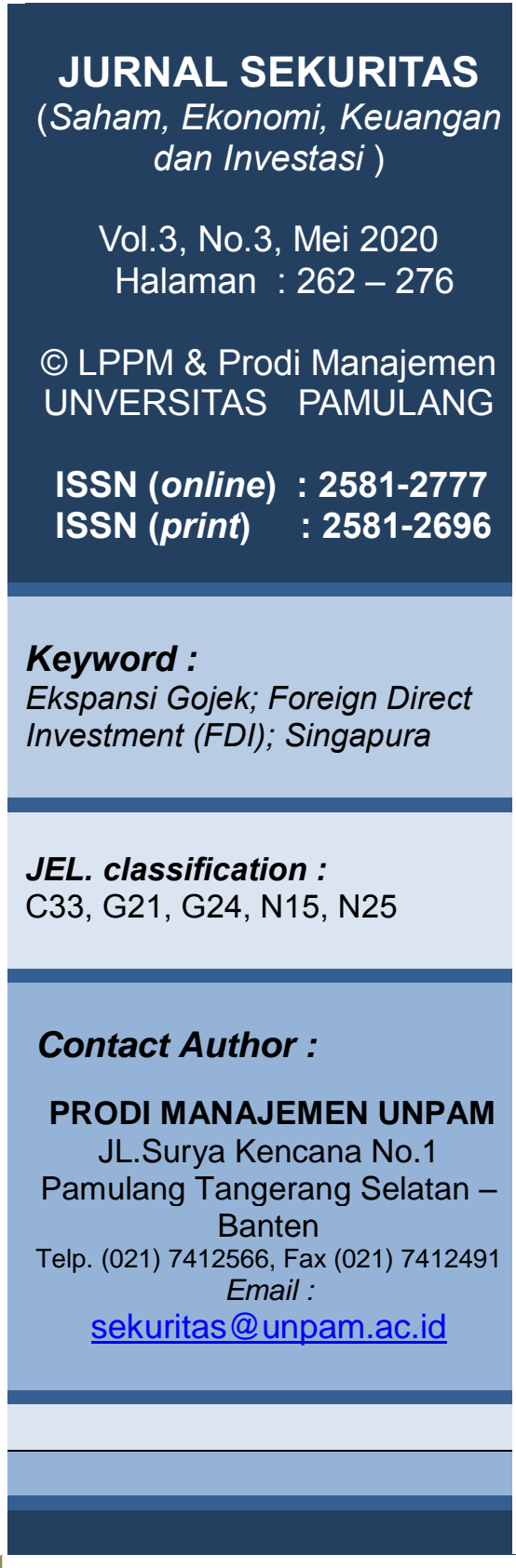

Gojek melakukan ekspansi ke sejumlah negara di kawasan Asia Tenggara pada tahun 2018. Salah satu negara tersebut ialah Singapura, ekspansi ini dinilai cukup berani. Singapura merupakan satu-satunya negara maju di Asia Tenggara, sekaligus sebagai negara asal raksasa ride hailing saingan Gojek, yakni Grab. Untuk itu, penelitian ini bertujuan untuk mengetahui faktor-faktor yang mempengaruhi ekspansi Gojek di Singapura tahun 2018. Penelitian ini merupakan penelitian deskriptif dengan teknis analisa kualitatif, dan mengumpulkan data menggunakan studi kepustakaan. Penelitian ini menggunakan konsep Foreign Direct investment (FDI), untuk menetapkan enam faktor penentu yang mempengaruhi ekspansi Gojek di Singapura. Hasil dari penelitian ini menunjukkan, jika setidaknya terdapat enam faktor penentu ekspansi Gojek di Singapura. Enam faktor tersebut ialah, pertumbuhan market size di Singapura, keterbukaan negara Singapura, rendahnya tingkat inflasi di Singapura, tingkat korupsi yang cenderung rendah di Singapura, adanya kebijakan pemerintah yang mendukung penanaman modal asing di Singapura, serta stabilitas politik yang tinggi di Singapura

Gojek expanded to a number of countries in the Southeast Asian region in 2018. One of these countries is Singapore, this expansion is considered quite brave. Singapore is the only developed country in Southeast Asia, as well as the home country of Gojek rival, Grab. For this reason, this study aims to determine the factors influencing the expansion of Gojek in Singapore in 2018. This research is a descriptive study with qualitative technical analysis, and collects data using literature studies. This study uses the concept of Foreign Direct Investment (FDI), to establish six determinants that affect Gojek expansion in Singapore. The results of this study indicate, if there are at least six determinants of Gojek expansion in Singapore. The six factors are, the growth of market size in Singapore, the openness of Singapore, the low level of inflation in Singapore, the level of corruption that tends to be low in Singapore, the existence of government policies that support foreign investment in Singapore, and high political stability in Singapore. 


\section{A. PENDAHULUAN}

Penelitian ini bertujuan untuk menganalisis ekspansi Gojek di Singapura pada tahun 2018, dengan mencari faktor-faktor penentu dari ekspansi tersebut. Bidang kajian yang difokuskan dalam penelitian ini ialah bidang ekonomi. Pembahasan dalam penelitian ini akan berkaitan erat dengan foreign direct investment (FDI), yang merupakan bagian dari kegiatan ekonomi internasional. Penjelasan yang paling utama akan berkesinambungan dengan faktor-faktor yang mempengaruhi investor dalam pelaksanaan FDI.

Globalisasi telah membawa manusia tidak berdaya dihadapan teknologi. Kebutuhan dan ketergantungan dengan teknologi tidak lagi dapat dielakkan. Hal ini sejalan dengan kemajuan teknologi dan inovasi yang terus berkembang dan merambah kepada segala sektor kehidupan. Perkembangan ini telah merubah kebiasaan dan juga gaya hidup seseorang secara luas (Achdiat, 2019). Sebutan yang tepat bagi era sekarang ini ialah era Revolusi Industri 4.0, yang merupakan produk dari globalisasi. Hasil revolusi ini ialah lahirnya kemajuan teknologi dan keberagaman inovasi teknologi digital. Revolusi Industri 4.0 sebagai produk dari globalisasi telah memberikan dampak pada bidang sosialbudaya, ekonomi, dan politik. Dari bidang sosial-budaya terdapat sejumlah kemudahan dalam pelaksanaan pertukaran budaya nasional suatu negara. Kemajuan teknologi dan pendidikan di era globalisasi menjadi pemicu dalam kegiatan pertukaran budaya sejumlah negara yang ada di dunia. Revolusi Industri ini kemudian memberikan kesempatan untuk dapat melihat dan mempelajari kebudayaan dari seluruh dunia hanya dengan mengakses internet. Pada bidang politik terjadi perbedaan dalam melakukan aksi-aksi politik. Aksi politik di era ini dilakukan melalui gerakan-gerakan berbasis media sosial. Pada bidang ekonomi terjadi peningkatan jumlah Start-up pada sektor penyedia barang dan jasa berbasis online yang kemudian dapat berkembang dengan cepat dan besar dengan berbagai ide dan inovasi yang ditawarkan (Aditya Hadi Pratama, 2017). Hal itulah yang menjadi nilai penting suatu perusahaan saat ini.

Gojek merupakan salah satu yang menawarkan inovasi dalam dunia digital. Melalui aplikasinya, Gojek dapat mempertemukan pengemudi dengan para pelanggan dalam suatu transaksi perjalanan. Gojek muncul karena permasalahan yang terdapat di dalam masyarakat Indonesia. Masalah pertama ialah pengemudi ojek yang kerap memberikan harga yang tidak sesuai dengan harapan pelanggan, terlebih untuk para pendatang yang baru saja mengenal suatu daerah. Kedua, terjadinya inefisiensi pasar dimana permintaan akan jasa ojek terkadang tidak terpenuhi karena tidak adanya pengemudi ojek saat itu atau sebaliknya. Dengan berbagai permasalahan yang muncul, Nadiem Makarim mulai melakukan inovasi dan menghadirkan Gojek di Indonesia (Virgina Maulita Putri, 2018). Pada awal berdirinya gojek di Indonesia pada tahun 2010, Gojek hanyalah sebuah layanan call center yang kemudian bertransformasi menggunakan aplikasi mobile untuk pemesanan jasa transportasi pada tahun 2015. Hal ini kemudian mampu memberikan kesepakatan antara pengemudi dan pelanggan melalui teknologi digital yang ditetapkan secara massal sehingga tidak terjadi kecurangan harga maupun monopoli. Selain itu, Gojek juga membantu pengemudi menemukan pelanggan. Inovasi Nadiem ini menjadi suatu inovasi atau ide segar bagi kegiatan perekonomian Indonesia.

Transformasi Gojek di tahun 2015 berhasil mengundang minat investor untuk mendukung Gojek. Rata-rata investasi yang masuk berasal dari pengusaha asing seperti Sequia Captial, Northstar, Softbank Vision Fund, Toyota Motor Corporation, Ping An Capital, Mirae Asset-Never Asia Growth Fund dan bahkan perusahaan Google pun turut menjadi investor besar yang bermain dalam perkembangan Gojek hingga mengantarkan perusahaan start-up ini menyandang status Decacorn pertama di Indonesia. Nilai valuasi Gojek ialah 10 milliar dollar AS atau setara dengan Rp.140 trilliun. Hingga 2019 mitra investasi yang diketahui telah bekerja sama dengan Gojek adalah Sequia Capital, Northstar, Google, Tencent, JD.com dan Holding company dengan nilai investasi yang 
besar. Tahun 2020 Gojek kembali mendapat suntikan dana sebesar 1,2 milliar US\$ atau setara dengan Rp.18 Trilliun (KataData, 2018).

Besarnya nilai investasi terus melancarkan ekspansi yang dilakukan oleh gojek. Pada September 2018 Nadiem Makarim sebagai pendiri Gojek meresmikan ekspansi usahanya ke negara tetangga Indonesia, Vietnam. Ekspansi ini sekaligus menandakan Gojek telah menajadi sebuah perusahaan mutinasional atau juga dikenal dengan istilah MNC.Upaya perluasan usaha gojek ke negara tetangga bertujuan untuk mengetahui jika model jasa berbasis online yang sama seperti Gojek, akan dapat diterapkan di negara yang berbeda (CNN Indonesia, 2018). Gojek tidak menggunakan nama yang sama dengan namanya di Indonesia, mereka berusaha melalukan pendekatan dengan menggunakan nama perusahaan yang lebih akrab dengan masyarakat lokal Vietnam. Goviet ditujukan kepada nama Gojek di Vietnam. Pada akhir tahun 2018 Gojek kembali melakukan ekspansinya ke Thailand dan Singapura (Andina Librianty, 2019). Gojek Thailand menggunakan nama Get sebagai nama adaptasinya. Kehadiran Gojek di negara tentangga ini memang disambut dengan antusisas oleh warga setempat. Hal tersebut terlihat dengan 1 juta pesanan yang diperoleh Gojek di Vietnam dan Thailand dalam kurun waktu 2-3 bulan (Rahajeng Kusumo Hastuti, 2018). Pada roda dua Goviet, pangsa pasar telah mencapai $40 \%$ pasca 6 bulan peluncurannya, angka yang hampir sama juga di berhasil diraih oleh Get (Rahajeng Kusumo Hastuti, 2018). Angka tersebut telah melahirkan persaingan terhadap Grab yang sudah terlebih dahulu masuk ke dalam Vietnam dan Thailand, yakni pada tahun 2013 (Roy Franedya, 2018). Gojek di Singapura telah mampu memasuki seluruh kawasan negara tersebut di Tanggal 2 Januari 2019. Perkembangan Gojek di Singapura tidak sepesat di dua negara lainnya, tentu saja karena masyarakat di sana telah terbiasa menggunakan Grab, produk asli negaranya (Roy Franedya, 2018).

Ekspansi Gojek di Singapura dinilai sebagai langkah yang cukup berani. Selain karena Singapura adalah satu-satunya negara maju di Asia Tenggara, tetapi juga karena Singapura memiliki raksasa ride hailing andalan mereka yakni Grab (Roy Franedya, 2018). Bergabungnya Gojek ke dalam negara asal pesaingnya, menunjukkan jika ada dorongan-dorongan tertentu yang diperimbangkan oleh Gojek untuk masuk ke Singapura. Ekspansi yang dilakukan oleh Gojek di Singapura telah menjadi hal yang menarik untuk diteliti. Oleh karena itu, melalui permasalahan yang telah dipaparkan, penelitian ini memiliki rumusan masalah, "Apa Faktor-Faktor yang Mempengaruhi Ekspansi Gojek di Singapura Tahun 2018?". Selaras dengan rumusan masalah yang ada, penelitian ini memiliki tujuan untuk mengetahui faktor-faktor yang mempengaruhi ekspansi Gojek di Singapura tahun 2018.

\section{B. KAJIAN LITERATUR}

Globalisasi dari pandangan Apridar yang kemudian dikutip oleh Herlan, dipandang sebagai yang menggambarkan peningkatan kesalinghubungan antarbangsa dan juga antarmanusia di dunia yang dilakukan melalui perdagangan, investasi, kebudayaan yang popular, serta berbagai interaksi lainnya yang menyebabkan ketidakjelasan batas-batas suatu negara (Herlan Firmansyah dan Endang Hendra, 2015, p. 47). Pada tulisan Agus yang mengutip Michael P. Todaro dikatakan jika globalisasi merupakan hasil dari perubahan di bidang ekonomi, politik, sosial serta bidang lainnya (Agus Sudarsono, 2013, p. 4). Selaras dengan pemikiran Michael P. Todaro, Tantri Abeng mengatakan jika terjadi perubahan dibidang ekonomi yang kemudian mengakibatkan kemunculan globalisasi perdagangan. Perubahan ini berwujud perilaku negara yang menurunkan dan menyerahkan tarif serta penghapusan berbagai hambatakan non-tarif dengan tujuan menciptakan iklim perdagangan yang cepat, ketat dan fair (Herlan Firmansyah dan Endang Hendra, 2015, p. 48).

Perubahan yang dijelaskan Michael P. Todarjo oleh Halwani yang dikutip Agus, diperkirakan muncul akibat berbagai faktor. Salah satu faktor tersebut ialah maraknya perkembangan multinational corporation (MNC) di hampir seluruh dunia (Agus 
Sudarsono, 2013, p. 5). MNC menurut Thomas Oatley merupakan sebuah perusahaan yang berbasis di sebuah negara yang kemudian menciptakan fasilitas produksi baru di negara asing atau membeli yang sudah ada dan memperluas kontrol manajerial hingga melintasi batas-batas negara (Thomas Oatley, 2004, p. 170). Menurutnya, perusahaan menjadi MNC ketika mereka melakukan foreign direct investment (FDI), bentuknya dapat dalam pembelian tanah, pembangunan pabrik, membangun anak perusahaan, dll.

FDI merupakan salah suatu konsep yang sering dibahas dalam ekonomi internasional. The Organization for Economic Cooperation and Development (OECD) mengartikan FDI sebagai, "Investasi lintas batas yang mencerminkam minat membangun yang berjangka panjang oleh seorang investor terhadap penduduk perusahaan milik perekonomian (negara) lain" (OECD Library, 2018). Sedangkan menurut Agiomirgianarkis, Asteriou dan Papathoma yang dikutip oleh Maria, FDI merupakan aliran modal yang dihasilkan dari perilaku perusahaan multinasional (Rolo, 2017, p. 5). Menurut Adrew Walter dan Gautam Sen, FDI dibagi menjadi dua bentuk utama. Bentuk pertama ialah FDI vertikal atau FDI pencarian biaya. FDI bentuk ini menekankan kegiatan produk yang dilakukan lebih dari satu lokasi untuk mendapatkan biaya yang lebih murah (Walter \& Sen, 2008, p. 198). Kemudian yang kedua merupakan FDI horizontal atau yang disebut FDI pencarian pasar. Bentuk ini melibatkan kegiatan produksi di pasar nasional (negara asal MNC) dan menekankan kepada pasar akhir untuk kegiatan distribusi (Walter \& Sen, 2008, p. 98). Penjelasan Walter dan Sen kemudian memperoleh dukungan dari Dunning. la menyampaikan jika terdapat tiga motivasi para aktor dalam melakukan FDI, yakni untuk pencarian sumber daya, efisiensi dan pasar baru (Rolo, 2017, p. 6).

Terdapat faktor-faktor penentu yang menyebabakan seorang investor asing ingin melakukan investasi atau mengembangkan usahanya ke negara tertentu. Menurut Dunning yang dikutip oleh Maria, FDI memiliki penentu yang kompleks dan tidak ada penjelasan tunggal untuk memahaminya (Rolo, 2017, p. 9). Faktor penentu tersebut memiliki ketergantungan dengan negara tempat investor berasal, oleh karenya faktor ini sangat relatif. Mephokee Cholpaisan dan Roopsom mengatakan jika faktor penentu dapat berasal dari motivasi investor, sektor investasi yang dilakukan, dan strategi masingmasing investor itu sendiri (Rolo, 2017, p. 9). Oleh Maria kemudian ditetapkan beberapa faktor penentu yang paling penting, seperti market size, openness, government policies, labor costs and productivity, politic risk, economic and financial stability, exchange rate valuation, corruption, business facilitation, infrastructure and institution, taxes, dan faktorfaktor penentu lainnya.

Pada penilitian ini penulis akan menggunakan konsep MNC yang dikemukakan oleh Thomas Oatley. la mengatakan jika, "MNC ialah sebuah perusahaan yang berbasis di sebuah negara yang kemudian menciptakan fasilitas produksi baru di negara asing atau membeli yang sudah ada dan memperluas kontrol manajerial hingga melintasi batasbatas negara" (Thomas Oatley, 2004, p. 170). Semikian pula dengan Gojek. Decacorn milik Indonesia ini pada awalnya hanya hadir di Indonesia, hingga melakukan ekspansi usahanya pada tahun 2018 di Vietnam, Thailand, dan Singapura. Ekspansi ini menjadikan Gojek sebagai Perusahaan Multinasional atau MNC yang menciptakan fasilitas produksi (transportasi) di negara asing hingga memperluas manajerialnya. Kemudian penelitian ini juga akan menggunakan konsep FDI yang dikemukakan oleh Dunning terkait faktor penentu FDI. la mengatakan jika faktor tersebut kompleks dan tidak dapat dijelaskan secara tunggal. Oleh karenanya, penelitian ini akan mengambil enam faktor penentu yang dipandang mampu menjelaskan faktor yang memperngaruhi ekspansi Gojek di Singapura. Enam faktor penentu tersebut ialah sebagai berikut:

a. Market Size, oleh Artige dan Nicoli yang dikutip oleh Maria mengatakan jika penentu ini diukur dengan PDB dan PDB perkapita (Rolo, 2017, p. 9). Ukuran pasar menjadi pengaruh karena investor sering berniat untuk berpindah ke negara berpasar besar dan melakukan ekspansi. Hal tersebut karena ada pengharapan jika akan terdapat daya beli yang lebih tinggi di negara dengan pasar besar. 
b. Openness, menurut Dermirham dan Masca penentu ini dihasilkan oleh rasio ekspor ditambah impor terhadap PDB atau juga dikenal sebagai rasio perdagangan-PDP (Rolo, 2017, p. 10). Rasio tersebut oleh Mephokee dkk. dipandang telah "mewakili kebijakan perdagangan bebas yang menghilangkan hambatan perdagangan, menciptakan fasilitas investasi dan mempromosikan perlindungan hak kekayaan intelektual' (Rolo, 2017, p. 10). Tingginya keterbukaan akan memberikan kemungkinan banyak negara untuk berinvestasi di suatu negara.

c. Economic and Financial Stability, merujuk pada pemikiran Assuancao, Forte dan Teixeira yang kutipan oleh Maria, faktor penentu ini merujuk pada tingkat inflasi suatu negara (Rolo, 2017, p. 11). Tingginya tingkat inflasi dipandang dapat meyebabkan kerusakan daya tarik investor, karena biasanya hal tersebut menggambarkan ketidakseimbangan ekonomi suatu negara.

d. Corruption, faktor penentu ini oleh beberapa penulis seperti Benassy Quere, Coupet \& Mayer, dan Cleeve dianggap sebagai pengaruh yang cukup nyata. Tingkat korupsi mampu mempengaruhi kapasitas pembangunan dan menentukan kualitas kelembagaan (Rolo, 2017, p. 15). Korupsi dapat menyebabkan besarnnya biaya transaksi yang dikenakan, sehingga menurunkan minat FDI.

e. Government Policies, pendapat dari Agiomirgianakis dkk. menyatakan jika kebijakan pemerintah yang dimaksud ialah bentuk tarif, pajak, subsidi, peraturan pemerintah dan kebijakan privatisasi (Rolo, 2017, p. 12). Hal tersebut sangat berpengaruh dalam kegiatan investasi, seperti pengenaan tarif tertentu yang akan meninggikan biaya investasi.

f. Political Risk, gagasan dari Edwards yang dikutip Maria menyatakan jika resiko politik memiliki dua penentu, yakni ketidakstabilan politik dan kekerasan politik (Rolo, 2017, p. 11). Yang paling utama ialah ketidakstabilan politik, hal ini dapat menggambarkan keadaan sutau negara. Ketidakstabilan negara dapat dimaknai sebagai kondisi yang memunculkan perubahan dalam pemerintahan, kebijakan ataupun aturan di negara tertentu.

\section{METODOLOGI PENELITIAN}

\section{Sifat Penelitian}

Penelitian ini merupakan penelitian deskriptif. Penelitian deskriptif merupakan penelitian yang dilakukan untuk memberikan penjelasan yang mendalam terkait suatu gejala, fakta atau kejadian secara sistematis dan akurat (Nurul Zuriah, 2009, p. 47). Penelitian ini termasuk ke dalam penelitian studi kasus. Penelitian studi kasus ialah penelitian yang bertujuan untuk mempelajari secara intensif mengenai unit sosial tertentu yang meliputi individu, kelompok lembaga dan masyarakat (Nurul Zuriah, 2009, p. 48). Kasus yang digunakan dalam penelitian ini ialah kegiatan ekspansi Gojek di Singapura pada tahun 2018. Penelitian ini menggunakan teknis analisa kualitatif. Penelitian kualitatif menurut Bodgan dan Tylor yang dikutip oleh Zuriah diartikan sebagai teknis tertentu di dalam ilmu pengetahuan sosial yang secara fundamental bergantung pada pengamatan terhadap manusia dalam kawasannya sendiri dan memiliki hubungan dengan orang-orang tersebut dalam bahasan dan peristiwanya (Nurul Zuriah, 2009, p. 92). Dengan demikian, penelitian ini merupakan penelitian deskriptif-kualitatif. Penelitian jenis ini menggunakan metode penjabaran dari data yang telah diolah dan dikumpulkan sebelumnya, merangkum informasi serta menggabungkannya untuk kemudian disajikan dalam rangkaian kata yang saling berkaitan.

\section{Metode Pengumpulan Data}

Metode pengumpulan data yang digunakan dalam tulisan ini ialah studi kepustakaan (Library Research). Pengumpulan data mennggunakan studi kepustakaan dipandang paling tepat untuk digunakan dalam peneltian ini. studi 
kepustakaan menggunakan buku, jurnal, skripsi, tesis, berita, dan bahan bacaan lainnya untuk mengumpulkan data (Uber Silalahi, 2009). Penulis akan menggunakan sumber bacaan yang berkaitan dengan faktor-faktor yang mempengaruhi ekspansi Gojek di Singapura tahun 2018.

\section{Sumber Data}

Data yang digunakan dalam penelitian ini ialah data primer dan data sekunder. Data primer di dapatkan langsung dan merupakan jenis data kuantitatif yang dikumpulkan dari waktu ke waktu untuk mengetahui perkembangan dari suatu keadaan. Data sekunder digunakan dengan mencari, mengumpulkan, membaca buku serta literature-literatur yang berkaitan dengan faktor ekspansi Gojek di Singapura tahun 2018.

\section{Batasan Ruang Lingkup Penelitian}

\section{a. Batasan Materi Penelitian}

Penulis menyadari jika faktor yang memperngaruhi ekspansi Gojek di Singapura tahun 2018 melalui FDI akan memiliki pembahasan yang luas. Oleh karena itu, penulis membatasi materi penelitian dengan menetapkan enam faktor penentu ekspansi Gojek di Singapura, diantaranya ialah market size, openness, economic and financial stability, corruption, government policies, dan political risk. Enam faktor penentu yang dipandang mampu menjelaskan faktor yang memperngaruhi ekspansi Gojek di Singapura pada tahun 2018.

\section{b. Batasan Waktu Penelitian}

Pembaruan keadaan suatu negara sangat mempengaruhi pertimbangan investor dalam melakukan ekspansi usahanya ke suatu negara. Untuk itu, penelitian ini memiliki batasan waktu antara 2015-2018. Batasan waktu penelitian ini dipandang telah tepat untuk mengetahui faktor penentu Gojek dalam ekspansi usahanya di Singapura tahun 2018.

\section{HASIL DAN PEMBAHASAN}

\section{Pertumbuhan Market Size Singapura}

Perusahan Gojek yang melahirkan bisnis ekonomi kreatif di Indonesia mendapatkan pujian dari pemerintah serta masyarakat dan para pelaku bisnis lainnya (Septanto, 2016). Pasca banyaknya investor asing yang menanamkan modal mereka di Gojek, perusahaan ini akhirnya melakukan ekspansi salah satunya di negara Singapura (Roy Franedya, 2018). Salah satu alasan Gojek memilih Singapura, ialah karena negara tersebut merupakann satu-satunya negara maju di Asia Tenggara. Ekspansi Gojek telah dipandang sebagai langkah yang berani, meskipun Singapura adalah negara maju perlu diingat jika negara ini adalah negara asal dari Grab yang merupakan saingan daropada Gojek. Penulis meyakini jika Gojek memiliki faktor pendorong lainnya, seperti Market Size (Ukuran Pasar).

Ukuran pasar merupakan kunci bagi para investor dalam mencari negara sebagai tempat mereka berinvestasi. Negara dengan pasar besar dan daya beli yang tinggi menjadi pertimbangan bagi para investor, karena berpeluang untuk mengembangkan bisnis mereka dengan pesat di negara tersebut (Rolo, 2017). Alat pengukur dari ukuran pasar ialah tingkat PDB dan PDB perkapita. Tingginya PDB di suatu negara belum tentu menggambarkan ekonomi penduduk yang tinggi. PDB atau Produk Domestik Bruto dalam bahasa internasionalnya lebih di kenal dengan GDP atau Gross Domestic Product. PDB memiliki dua fungsi, yakni untuk mengukur total pendapatan perekonomian semua orang dan mengukur total dari perekonomian suatu negara dalam pembelanjaan negara (Santoso, 2011). PDB perkapita merupakan saham dari anggota individu dari populasi terhadap PDB tahunan, dan pendapatan perkapita menjadi ukuran untuk menggambarkan standar hidup penduduk suatu negara (standard of living). Dengan demikian, negara yang memiliki 
pendapatan perkapita yang tinggi akan mampu memiliki standar hidup yang juga tinggi (Masniadi, 2012). PDB per kapita ini merupakan ukuran rata-rata kesejahteraan perorangan yang cukup alamiah, lebih menunjukan apa yang terjadi pada perekonomian rata-rata penduduk (Santoso, 2011).

PDB Singapura cenderung mengalami peningkatan setiap tahunnya. PDB Singapura pada April 2014 adalah USD 77 juta, jumlah ini kemudian tumbuh di bulan Juli tahun 2015 menjadi USD 78,5 juta (CEIC Data, 2020). Pada April 2016 PDB Singapura menyentuh angka USD 76,2 juta dan mengalami kenaikan pesat pada April 2017 menjadi USD 82,5 juta (CEIC Data, 2020). Mengawali tahun 2018, Singapura memiliki jumlah PDB hingga USD 89,9 juta, hampir menyentuh angka USD 90 juta (CEIC Data, 2020). Tingginya PDB Singapura ini, memperlihatkan jika negara tersebut memiliki pendapatan perekonomian dan pembelanjaan negara yang tinggi. PDB Singapura hingga tahun 2018 menjadi PDB tertinggi di kawasan Asia Tenggara.

Grafik 1. PDB Perkapita Singapura tahun 2014-2018

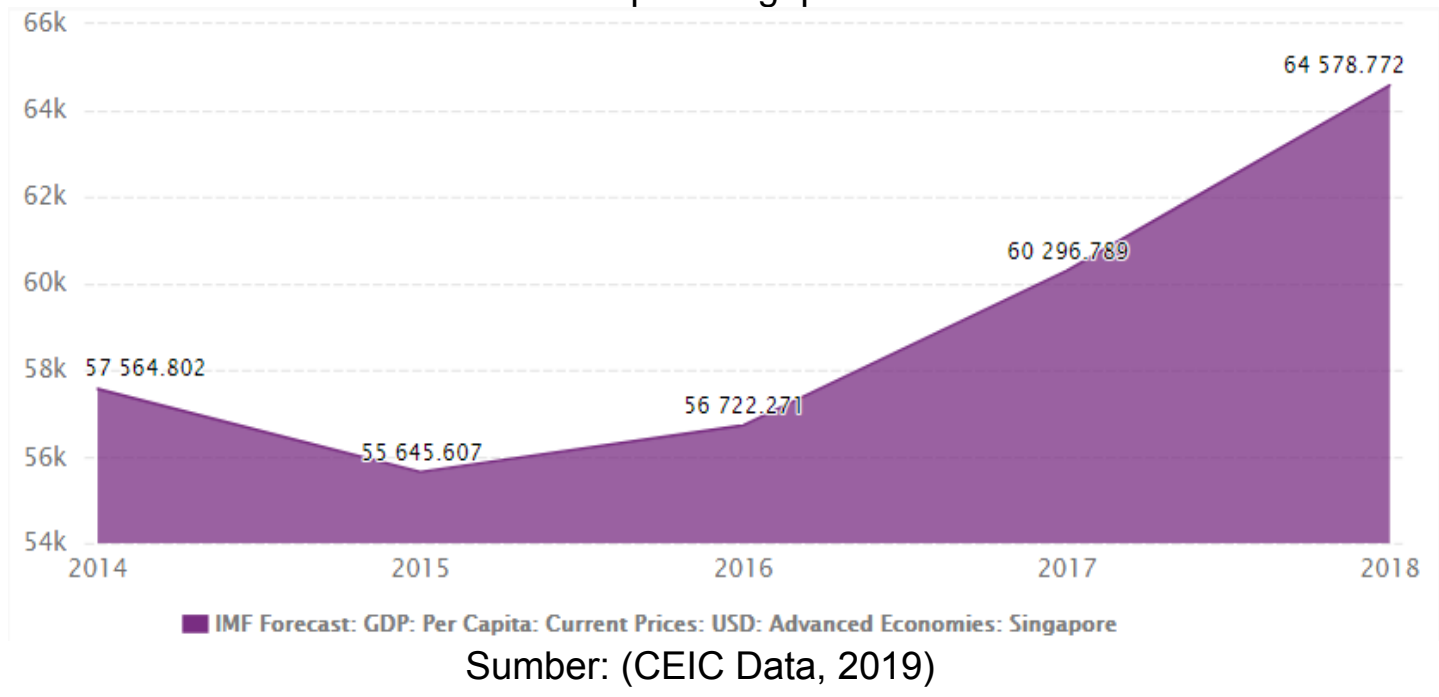

Pada Grafik 1. di atas terdapat data PDB perkapita Singapura yang di perbaharui dari tahun ke tahun. PDB perkapita Singapura dalam rentang tahun 2015-2018 hampir mengalami peningkatan hingga dua kali lipat. Pada tahun 2015 PDB perkapita Singapura ialah USD 55,6 juta, jumlah ini kemudian berkembang di tahun 2016 menjadi USD 56,7 juta dan kembali meningkat menjadi USD 60,2 juta di tahun 2017 (CEIC Data, 2019). PDB perkapita tertinggi Singapura diraih pada tahun 2018 dengan total USD 64,5 juta (CEIC Data, 2019).

Pertumbuhan pesat market size milik Singapura yang terlihat dari peningkatan pada PDB dan PDB perkapita, telah mendukung potensi Singapura untuk menumbukan kegiatan FDI di negaranya. Oleh karena itu, Singapura menjadi negara yang menarik perhatian investor asing, salah satunya ialah Gojek yang melakukan ekpansinya di akhir tahun 2018.

\section{Keterbukaan Singapura dalam Penanaman Modal Asing}

Keterbukaan memperlihatkan posisi persaingan negara dalam perdagangan international. Mengukur keterbukaan negara dapat dilakukan dengan melihat rasio ekspor dan impor terhadap PDB (Rolo, 2017, p. 10). Adanya fasilitas perdagangan bebas akan menghilangkan hambatan-hambatan perdagangan dan menciptakan fasilitas investasi serta meningkatkan perlindungan hak milik. Sehingga keterbukaan menjadi salah satu faktor penting bagi para investor, dalam memilih negara tujuan investasi usahanya. 
Tabel 1. Nilai Impor dan Ekspor Singapura Tahun 2014-2018

\begin{tabular}{|c|c|c|c|}
\hline No. & Tahun & Nilai Impor & Nilai Ekspor \\
\hline $\mathbf{1 .}$ & 2014 & 377.938 Juta & 415.418 Juta \\
\hline $\mathbf{2 .}$ & 2015 & 308.122 Juta & 357.941 Juta \\
\hline 3. & 2016 & 291.908 Juta & 338.082 Juta \\
\hline 4. & 2017 & 327.710 Juta & 373.225 Juta \\
\hline 5. & 2018 & 370.504 Juta & 411.743 Juta \\
\hline
\end{tabular}

Sumber: (Word Intergrated Trade Solution (WITS), 2020)

Tabel 1. di atas merupakan data dari kegiatan ekpor dan Impor Singapura. Terlihat jika negara tersebut akif dalam melakukan perdagangan bebas. Nilai impor Singapura sempat mengalami penurunan di tahun 2015 hampir USD 70 juta dan kembali menurun di tahun 2016 hingga nilai impor hanya mencapai angka USD 291 juta. Namun, peningkatan terjadi di tahun 2017 dan 2018. Perkembangan impor ini juga dibarengi dengan peningkatan nilai ekspor yang sempat menurun di tahun 2015 dan 2016. Nilai ekspor yang semula mencapai USD 415 juta turun hingga lebih dari USD 50 juta menjadi USD 357 juta di tahun 2015. Tahun berikutnya ekspor Singapura masih mengalami penurunan dan mengalami kenaikan di tahun 2017. Nilai ekpor yang hanya sekitar USD 338 juta naik menjadi USD 373 juta. Pada tahun 2018 nilai ekspor Singapura mengalami kenaikan hingga USD 40 juta, sehingga mampu menyentuh angka USD 411 juta.(Word Intergrated Trade Solution (WITS), 2020)

Representasi keterbukaan ekonomi dan pergerakan pertumbuhan ekonomi, dapat ditunjukan dengan pertumbuhan aliran modal asing dan keikutsertaan negara dalam perdagangan internasional (Suliswanto, 2016). Kegiatan impor dan ekspor yang dilakukan oleh Singapura sudah lebih dari cukup untuk menggambarakan aktifnya kegiatan perdagangan internasional di negara tersebut. Singapura menjadi negara paling ramah akan bisnis internasional dari seluruh negara Asia Tenggara lainnya (Suliswanto, 2016).

Tidak hanya kegiatan perdagangan internasional, Singapura juga memaksimalkan potensi negaranya untuk mendapatkan aliran modal asing. Singapura merupakan negara yang memiliki sarana dan prasana (teknologi) terbaik di Asia Tenggara. Ketersedian fasilitas yang mereka berikan ditujukan untuk menunjang arus FDI di negaranya (Suliswanto, 2016). Akibat kemaksimalannya dalam menyiapkan pertumbuhan FDI ini, Singapura telah memiliki reputasi baik di mata investor asing. Singapura pada kenyatannya merupakan negara yang termasuk dalam peringkat sepuluh besar dunia, sebagai negara paling terbuka, inovatif dan kompetitif. Keterbukaan Singapura dalam kegiatan FDI jelas menarik perhatian investor asing. Kelancaran perdagangan atau bisnis mereka akan terjamin melalui keterbukaan yang ada. Hal ini juga menjadi salah satu faktor pendorong bagi Gojek dalam melakukan ekspansi usahanya di Singapura tahun 2018.

\section{Stabilitas Tingkat Inflasi di Singapura}

Untuk mengukur stabilitas ekonomi dan keuangan negara, jika merujuk pada pemikiran Assuancao, Forte dan Teixeira yang dikutip oleh Maria, maka faktor penentunya adalah tingkat inflasi suatu negara (Rolo, 2017, p. 11). Inflasi merupakan keadaan meningkatnya harga barang secara umum yang terjadi secara terusmenerus, akibat ketidaklancaran pendistribusian barang atau karena berbagai macam faktor lainnya (Suliswanto, 2016, p. 17). Tingginya tingkat inflasi dipandang dapat meyebabkan kerusakan daya tarik investor, karena biasanya hal tersebut menggambarkan ketidakseimbangan ekonomi suatu negara. Oleh karena itu, pada pembahasan kali ini akan dicari tahu tingkat inflasi Singapura sebelum ekspansi Gojek di akhir tahun 2018. 
Penelitian yang dilakukan oleh Subekti dan Worokinasih, ditemukan pembuktian jika inflasi di Singapura sejak tahun 2002-2016 mempengaruhi arus FDI yang masuk ke dalam negaranya. Pada periode tersebut, Singapura memiliki tingkat inflasi yang stabil dan lebih sering mengalami penurunan (deflasi) (Subekti \& Worokinasih, 2018, p. 190). Menurut mereka kestabilan tingkat inflasi ini kemudian menjadi daya tarik bagi investor asing untuk melakukan investasi ke negara tersebut.

Grafik 2. Inflasi Singapura Tahun 2016-2018

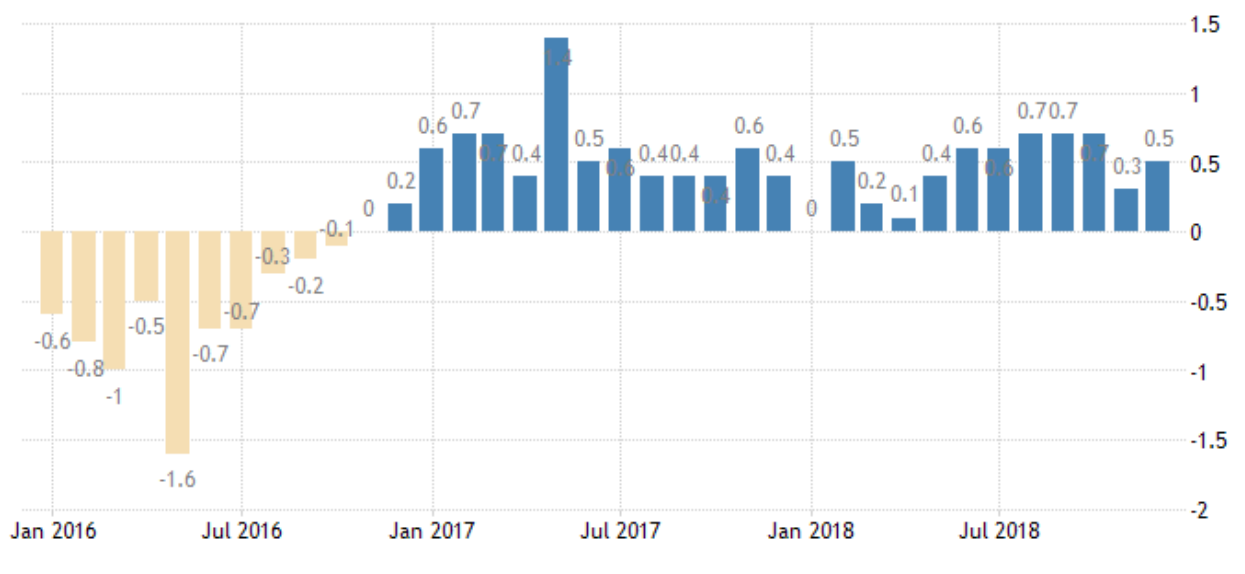

Sumber: (Trading Economics, 2020)

Berdasarkan Grafik 2. di atas, terlihat jelas jika tingkat inflasi di Singapura bahkan tidak pernah mencapai angka 2\%. Penurunan drastis terjadi di tahun 2016 dengan menyentuh angka $-1,6 \%$. Kemudian, ditahun 2017, inflasi tertinggi dia ngka 1,4\% dengan kenaikan $1 \%$ dari inflasi sebelumnya. Namun, setelahnya angka inflasi cenderung stabil sehingga beberapa kali berada di angka 0,40\%. Memasuki tahun 2018, inflasi Singapura mengalami penurunan dan mencapai angka terndah hingga $0,1 \%$. Hingga pertengahan 2018, inflasi Singapura tidak pernah mencapai angka $1 \%$, dengan angka tertingginya 0,7\% saja. (Trading Economics, 2020)

Tingkat inflasi Singapura sangat stabil jika dibandingkan dengan negara-negara Asia Tenggara lainnya, seperti Myanmar, Kamboja, dan Laos. Tingkat inflasi Myanmar di tahun 2016 mencapai titik tertingginya hingga 9,6\%, di tahun 2017 angka tersebut berubah menjadi 7,99\% (Trading Economics, 2018). Sedangkan inflasi di negara Kamboja mengalami kenaikan hampir dua kalipat. Pertengahan 2016 inflasi tersebut hanya dikisaran angka $2,9 \%$ kemudian naik menjadi $4,42 \%$ pada awal Januari (Trading Economics, 2019). Laos mengalami pelonjakan jumlah inflasi di awal tahun 2017, yang juga hampir dua kali lipat dari tahun sebelumnya. Pada pertengahan 2016, tingkat inflasi hanya sekitar 0,96\%, kemudian meningkat hingga 2,27\% di awal tahun 2017 (Trading economics, 2018). Peningkatan inflasi ini bisa diartikan sebagai ketidakstabilan perekonomian dan keuangan negara tersebut.

Jika dibandingkan dengan sejumlah negara lain di kawasan Asia Tenggara yang sering mengalami pelonjakan tingkat inflasi, maka investor asing akan lebih memilih Singapura sebagai tempat mereka berinvestasi. Kestabilan tingkat inflasi Singapura telah menggambarkan keseimbangan di dalam perekonomian dan keuangan negara tersebut. Dengan demikian, hal ini dapat menjadi salah satu faktor penentu bagi Gojek dalam memilih Singapura sebagai negara tujuan pengembangan usahanya.

\section{Tingkat Korupsi yang Rendah di Singapura}

Tingkat korupsi mampu mempengaruhi kapasitas pembangunan dan menentukan kualitas kelembagaan (Rolo, 2017, p. 15). Korupsi dapat menyebabkan 
besarnnya biaya transaksi yang dikenakan sehingga menurunkan minat FDI. Pada pembahasan kali ini akan dijelaskan tentang tingkat korupsi di Singapura, sebelum masuknya Gojek ke negara tersebut.

Singapura termasuk negara dengan tingkat korupsi yang kecil, jika dibandingkan dengan sejumlah negara lainnya di dunia. Hal ini dilihat melalui indeks persepsi korupsi dunia atau dengan nama lain Transparency International (TI). Pada tahun 2017, dilakukan penukuran tingkat korupsi, yang diikuti oleh 180 negara di dunia. TI menjelaskan bahwa skor yang mereka berikan terkait tingkat korupsi, diukur dari nilai 0-100. Dimana negara yang sangat kotor dan memiliki tingkat korupsi yang tinggi akan diberikan nilai mulai 0 , sedangkan negara yang paling bersih atau rendah akan korupsi di berikan nilai tertinggi hingga 100. Hasilnya, pada tahun tersebut Singapura mendapatkan nilai 84 dari 100 poin (Transparency International, 2017). Hal tersebut menempatkan Singapura ke peringkat kedua setelah Selandia Baru di wilayah asia pasifik yang memperoleh skor 84 (Sri Handayani, 2018). Jika dilihat rekam jejak sebelumnya, Singapura selalu memperoleh angka yang tinggi oleh TI. Pada tahun 2015 , Singapura mendapatkan nilai 85 , tahun berikutnya ia memperoleh angka 84 , kemudian di tahun 2018 Singapura kembali mendapatkan angka 85 (Transparency International, 2019). Tingginya angka ini membuktikan jika tingkat korupsi di Singapura sangatlah kecil dan cenderung stabil dari tahun ketahun.

Kecilnya tindakan korupsi di Singapura tidak terlepas dari sejumlah aturan terkait korupsi yang mengikat negara tersebut. Salah satunya ialah Singapore Prevention of Corruption Act. Aturan ini berisi tentang hukuman yang berlaku bagi tersangka korupsi di Singapura. Di dalamnya terdapat penjelasan jika individu atau kelompok yang menerima gratifikasi atau melakukan tindak korupsi akan dikenakan denda yang tidak lebih dari $\$ 100.000$ dan dipenjara tidak lebih dari 5 tahun (Lis Yuliawati, 2019). Gratifikasi yang dimaksudkan dapat berupa properti, uang, janji, dan atau layanan.

Jadi, rendahnya tingkat korupsi Singapura berdasarkan penilaian yang diberikan oleh TI sejak tahun 2015-2018 dapat memicu ketertarikan investor asing. Hal tersebut disebebkan oleh kecilnya kemungkinan pembengkakan biaya administrasi atau penyalahgunaan kuasa dalam pengurusan usaha, yang disebabkan oleh tindakan korupsi pejabat dan staf lainnya. Kecilnya tingkat korupsi ini juga dapat menjadi salah satu faktor yang menarik Gojek untuk melakukan ekspansi ke negara Singapura di tahun 2018.

\section{Dukungan Kebijakan Pemerintah Singapura Terhadap Investasi Asing Langsung}

Kebijakan yang dibentuk pemerintah dalam rangka mendukung masuknya investasi dari luar ke dalam negeranya, telah menjadi variabel penting bagi investor. Para investor secara rasional akan berinvestasi pada negara yang memiliki kebijakan-kebijakan yang mempermudah dan menguntungkan bagi mereka. Kebijakan ini dapat berupa kemudahan regulasi dan administrasi, rendahnya pajak yang harus dibayarkan, penerapan standar pada sektor usaha tertentu yang tidak menyulitkan, dan juga beberapa kebijakan lain yang turut memudahkan investor (Santander, 2020).

Pemerintah Singapura dalam strateginya untuk mendapatkan investasi dari luar, menetapkan sejumlah kebijakan yang yang mendukung kegiatan tersebut. Dua diantarnya ialah, pemberian pinjaman kepada investor asing dan insentif dan pembebasan pajak. Selain dua kebijakan tersebut, Singapura juga memiliki sejumlah undang-undang yang mendukung bisnis baik nasional maupun internasional. Selanjutnya ada pula kemudahan administrasi dan birokrasi yang ditujukan kepada para investor asing. Melalui kebijakan-kebijakan yang ada, Singapura berharap mampu menarik minat investor asing, untuk berinvestasi secara langsung di negaranya. 
Pertama, adanya pemberian pinjaman bagi investor asing untuk mengembangkan usahanya. Kebijakan ini jelas memberikan daya tarik besar bagi para investor asing (Open Company Singapore, 2020). Pembentukan kebijakan ini dilandasi oleh kondisi para investor di Singapura. Mereka memiliki persaingan bisnis yang ketat. Sehingga dalam persaingannya, pihak-pihak tertentu masih terkendala oleh sejumlah kesulitan. Maka dari itu, pemerintah Singapura mengeluarkan kebijakan untuk memberikan pinjaman kepada para investor asing. Tujuannya, agar para investor tidak khawatir untuk bersaing dan berinvestasi di Singapura. Skema pemberian pinjaman ini dapat diajukan langsung melalui pemerintah Singapura ataupun bank-bank di Singapura. Salah satu contoh bank tersebut ialah HSBC, yang memberikan skema pinjaman maupun penggadaian bagi investor asing. Perusahaan Gojek yang baru berekspansi ke Singapura dapat memanfaatkan hal ini untuk mengembangkan usahanya. Dengan demikian, Gojek dapat mengurangi kekhawatirannya dengan pesaing terberat usaha mereka, yakni Grab. Sekalipun Grab adalah MNC asal Singapura yang jelas telah terlebih dahulu memberikan pelayanan pada bidang jasa yang sama, tetapi Gojek tetap berpeluang dalam mengimbangi eksistensi Grab di Singapura.

Kebijakan kedua yang menarik perhatian investor adalah pemberian insentif dan pembebasan pajak. Pemerintah Singapura memberikan keringanan pajak bagi beberapa sektor usaha yang diinvestasikan di negaranya. Kebijakan ini akan menguntungkan bagi perusahaan kecil dan juga menengah yang sedang berinvestasi dan berkembang di Singapura. Pajak barang dan jasa yang diterapkan oleh Singapura memiliki nilai yang rendah, yaitu diangka 7\%. Angka ini merupakan nilai terkecil bagi pajak barang dan jasa se-Asia Pasifik (Open Company Singapore, 2020). Kebijakan ini jelas akan memberikan keuntungan yang cukup besar bagi investor yang bergerak dalam bidang barang dan jasa. Peluang tersebut, dapat menjadi salah satu pertimbangan Gojek yang berekspansi di Singapura pada tahun 2018.

Pemerintah Singapura juga mempermudah masuknya investasi asing dengan cara-cara lainnya, seperti memudahkan administrasi dan juga birokrasi. Pada kasus di beberapa negara lain, proses administrasi dan regulasi masuknya investor pada suatu negara sering kali mengalami permasalahan. Beberapa contoh dari permasalahan yang ada ialah, ketidaksesuaian dengan hukum yang berlaku, lamanya proses administrasi dan juga penerapan standar yang menyusahkan bagi para investor. Untuk menghindari permasalahan tersebut, maka pemerintah Singapura menyederhanakan proses administrasi dan birokrasi investor yang ingin masuk ke negaranya.

Kesuksesan Singapura dalam penerapan kebijakan yang bertujuan untuk memudahkan masuknya investasi asing ke negaranya, telah mereka rasakan di tahun 2018. Berdasarkan UNCTAD, Singapura menjadi negara terbesar ke-4 yang menerima aliran FDI pada tahun 2018 (Nordea Trade, 2020). Dengan demikian, melalui dukungan kebijakan yang diberikan oleh pemerintah Singapura terhadap arus investasi asing, telah mampu menjadi salah satu faktor pendorong bagi Gojek dalam melakukan ekspansi usahanya di Singapura tahun 2018.

\section{Tingkat Stabilitas Politik di Singapura}

Keadaan politik mampu mempengaruhi investor untuk berinvestasi pada suatu negara. Keadaan politik yang dimaksud disini adalah stabilitas politik yang tengah berlangsung di suatu negara. Keamanan negara juga turut menjadi aspek penting bagi pertimbangan investor, dalam memilih negara tujuan pengembangan usahanya. Bagi para investor, negara yang minim dengan konflik antar aktor politik dalam pemerintahan, dan juga minim konflik dengan korupsi menjadi tempat yang aman untuk menginvestasikan uang mereka. Banyaknya konflik disutau negara menggambarkan ketidakmampuan pemerintah, dalam menjaga keamanan dan 
kestabilan kondisi politik negaranya. Secara langsung maupun tidak langsung, hal tersebut akan mempengaruhi kondisi perekonomian suatu negara. Tingginya jumlah konflik mampu melemahkan mata uang, memberikan celah pada praktik-praktik kolusi maupun nepotisme, dan juga dapat memicu perpecahan warga negara. Stabilitas politik juga lebih sering ditemui pada negara maju dibanding dengan negara berkembang. Pada negara berkembang, kepentingan antar aktor bisa saja bersimpangan dan menyebabkan stabilitas terganggu. Hal tersebut secara rasional akan menurunkan keuntungan bagi investor atas keadaan negara yang tidak stabil. Seperti yang terlihat pada Gambar 1. di bawah ini, Singapura menjadi negara dengan index stablititas politik tertinggi dan berada pada posisi 3 besar pada tahun 2018,

Political stability index (-2.5 weak: 2.5 strong). 2018 (points, Source: The World Bank, TheGlobalEconomy.com)
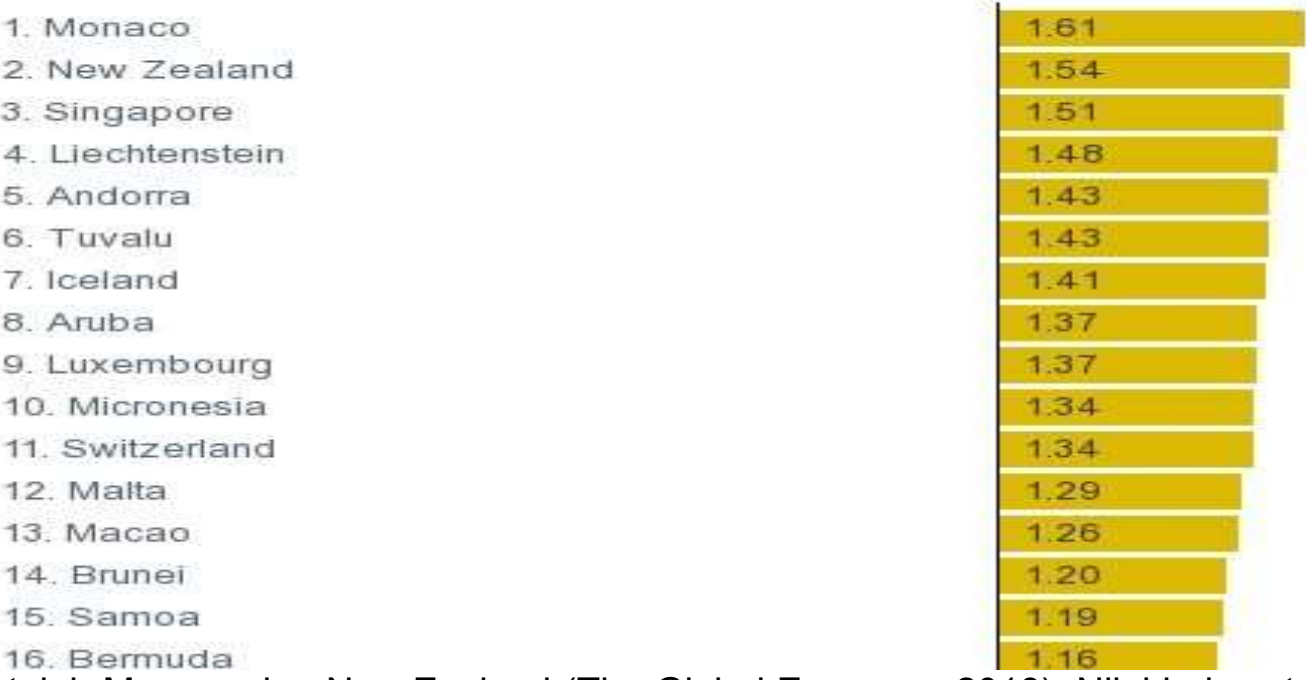

setelah Monaco dan New Zealand (The Global Economy, 2018). Nilai index stabilitas politik yang diraih Singara mencapai angka 1,51. Hal ini menunjukkan jika Singapura merupakan negara di kawasan Asia Tenggara yang memiliki index stabilitas politik tertinggi, dan disusul oleh Brunei Darussalam dengan peringkat ke-14 dunia.

Sumber: (The Global Economy, 2018)

Gambar 1. Peringkat Stabilitas Politik Negara di Dunia Tahun 2018

Gojek melihat secara rasional mengenai rencana ekspansi pada singapura berdasarkan hal ini. Singapura memiliki pemerintahan yang bersih dan juga dari tahun ke tahun menunjukan bahwa pemerintah singapura secara konstan dapat menjaga stabilitas politik, meski berada pada kondisi politik dunia yang tengah berubah-ubah. Hal ini telah menjadi jaminan tersendiri bagi keamanan penanaman modal asing di Singapura. Jelas keadaan seperti ini sangat menguntungkan Singapura, karena para investor cenderung berpikiran untuk menanamkan modal mereka di negara yang aman. Investasi pada negara tertentu dapat berlangsung dalam kurun waktu yang lama dan diharapkan memberikan keuntungan yang maksimal.

Jadi, jika dibandingkan dengan negara-negara Asia Tenggara lainnya, maka Singapura memiliki index stabilitas politik yang cukup tinggi. Jaminan rasa aman memberikan kepercayaan para investor untuk menanamkan modal mereka ke negara tersebut. Gojek yang memberikan pelayanan dalam bidang jasa pada masyarakat, sebenarnya hanya berdampak kecil atas keadaan politik yang tengah terjadi pada suatu negara (Kurecic \& Kokotovic, 2017). Namun, jika stabilitas politik pada Singapura terganggu hingga menyebabkan pelemahan ekonomi berupa inflasi maupun daya beli masyarakat menurun, maka akan berimbas pada keuntungan yang 
mampu diraih oleh Gojek. Dengan demikian, tingginya tingkat stabilitas politik di Singapura mampu menghadirkan kepercayaan kepada Gojek untuk melakukan ekspansi di negara tersebut.

\section{E. KESIMPULAN}

Berdasarkan pembahasan di atas, dapat disimpulkan jika setidaknya terdapat enam faktor penentu ekspansi Gojek di Singapura. Pertama ialah pertumbuhan market size Singapura yang pesat, terlihat dari peningkatan pada PDB dan PDB perkapita negara tersebut. Kedua, Singapura merupakan negara yang sangat terbuka akan perdagangan internasional, serta terbuka dengan masuknya aliran FDI ke negara mereka. Ketiga, tingkat inflasi Singapura cenderung stabil jika dibandingkan sejumlah negara di kawasan Asia Tenggara lainnya. Keempat, Singapura memiliki tingkat korupsi yang rendah. Kelima, terdapat sejumlah kebijakan pemerintah yang mendukung masuknya penanaman modal asing ke negara tersebut. Keenam, Singapura memiliki stabilitas politik yang tinggi. Faktor-faktor tersebut telah memberikan ketertarikan, kepercayaan, dan keinginan bagi investor asing untuk menanamkan modal mereka ke Singapura. Salah satu investor tersebut ialah Gojek, yang melakukan ekspansi usahanya ke Singapura pada tahun 2018.

\section{DAFTAR PUSTAKA}

Achdiat, I. (2019). Era Transportasi Menuju Industri 4.0. Retrieved March 27, 2020, from airmagz.com website: https://www.airmagz.com/41575/era-transportasi-menuju-industri4-0.html

Aditya Hadi Pratama. (2017). Perkembangan Startup Indonesia Pada Tahun 2018 Menurut Investor. Retrieved March 27, 2020, from techinasia website: https://id.techinasia.com/prediksi-perkembangan-startup-indonesia-2018

Andina Librianty. (2019). Gojek Tertarik Hadirkan Layanan GoFood di Singapura - Tekno Liputan6.com. Retrieved March 27, 2020, from liputan6.com website: https://www.liputan6.com/tekno/read/4018878/gojek-tertarik-hadirkan-layanan-gofooddi-singapura

CEIC Data. (2019). Singapura Pdb Per Kapita [1960 - 2018]. Retrieved April 11, 2020, from ceicdata.com website: https://www.ceicdata.com/id/indicator/singapore/gdp-per-capita

CEIC Data. (2020). Singapura PDB [1975 - 2020]. Retrieved April 11, 2020, from ceicdata.com website: https://www.ceicdata.com/id/indicator/singapore/nominal-gdp

CNN Indonesia. (2018). Ekspansi ke Singapura, Gojek "Incar" Ratusan Karyawan Baru. Retrieved March 27, 2020, from cnnindonesia.com website: https://www.cnnindonesia.com/teknologi/20180723175908-185-316372/ekspansi-kesingapura-gojek-incar-ratusan-karyawan-baru

KataData. (2018). Berapa Kali Gojek Mendapatkan Pendanaan dari Investor? Retrieved March 27, 2020, from Katadata.co.id website: https://databoks.katadata.co.id/datapublish/2018/02/12/berapa-kali-gojek-mendapatkanpendanaan-dari-investor

Lis Yuliawati, R. F. (2019). Ramai di Medsos Hukuman Koruptor di Singapura, Ini Bedanya dengan RI. Retrieved April 15, 2020, from vivanews.com website: https://www.vivanews.com/berita/nasional/8684-ramai-di-medsos-hukuman-koruptor-disingapura-ini-bedanya-dengan-ri?medium=autonext

Nordea Trade. (2020). Foreign direct investment (FDI) in Singapore. Retrieved April 12, 2020, from nordeatrade.com website: https://www.nordeatrade.com/en/explore-newmarket/singapore/investment 
OECD Library. (2018). Foreign direct investment (FDI). Retrieved from https://www.oecdilibrary.org/finance-and-investment/foreign-direct-investment-fdi/indicatorgroup/english_9a523b18-en

Open Company Singapore. (2020a). Paying Taxes in Singapore. Retrieved April 12, 2020, from opencompanysingapore.com website: https://www.opencompanysingapore.com/paying-taxes-in-singapore

Open Company Singapore. (2020b). Why Is Singapore Attractive for Foreign Investors? Retrieved April 12, 2020, from opencompanysingapore.com website: https://www.opencompanysingapore.com/why-is-singapore-attractive-for-foreigninvestors

Rahajeng Kusumo Hastuti. (2018). Sudah Menang di RI, Ini Alasan Gojek Ngotot Ekspansi ke ASEAN. Retrieved March 27, 2020, from cnbcindonesia.com website: https://www.cnbcindonesia.com/tech/20190724164459-37-87315/sudah-menang-di-riini-alasan-gojek-ngotot-ekspansi-ke-asean

Roy Franedya. (2018). Sudah Kuasai Pasar, Grab Cuekin Go-Jek di Singapura. Retrieved March 27, 2020, from cnbcindonesia.com website: https://www.cnbcindonesia.com/tech/20181211145736-37-45868/sudah-kuasai-pasargrab-cuekin-go-jek-di-singapura

Santander. (2020). Foreign investment in Singapore. Retrieved April 12, 2020, from Santandertrade.com website: https://santandertrade.com/en/portal/establishoverseas/singapore/foreign-

investment?actualiser_id_banque=oui\&id_banque=0\&memoriser_choix=memoriser\&\&a ctualiser_id_banque $=$ oui\&id_banque $=0 \&$ memoriser_choix $=$ memoriser

Sri Handayani. (2018). Singapura Masuk 10 Besar Negara dengan Korupsi Terkecil. Retrieved April 15, 2020, from replubika.co.id website: https://www.republika.co.id/berita/internasional/global/18/02/23/p4klwp328-singapuramasuk-10-besar-negara-dengan-korupsi-terkecil

The Global Economy. (2018). Political stability by country, around the world. Retrieved April 12, 2020, from TheGlobalEconomy.com website: https://www.theglobaleconomy.com/rankings/wb_political_stability/

Trading economics. (2018). Laos - Tingkat Inflasi. Retrieved April 15, 2020, from id.tradingeconomics.com website: https://id.tradingeconomics.com/laos/inflation-cpi

Trading Economics. (2018). Myanmar - Tingkat Inflasi. Retrieved April 15, 2020, from id.tradingeconomics.com website: https://id.tradingeconomics.com/myanmar/inflationcpi

Trading Economics. (2019). Kamboja - Tingkat Inflasi. Retrieved April 15, 2020, from id.tradingeconomics.com website: https://id.tradingeconomics.com/cambodia/inflationcpi

Trading Economics. (2020). Singapura - Tingkat Inflasi. Retrieved April 15, 2020, from id.tradingeconomics.com website: https://id.tradingeconomics.com/singapore/inflationcpi

Transparency International. (2017). Transparency International - Singapore. Retrieved April 15, 2020, from transparency.org website: https://www.transparency.org/country/SGP

Transparency International. (2019). Corruption Perceptions Index 2015-2019. Retrieved April 15, 2020, from transparency.org website: https://www.transparency.org/cpi2019\#results

Virgina Maulita Putri. (2018). Nadiem Ungkap Asal Muasal Ide Bikin Go-Jek. Retrieved March 27, 2020, from detik.com website: https://inet.detik.com/cyberlife/d4095485/nadiem-ungkap-asal-muasal-ide-bikin-go-jek

Word Intergrated Trade Solution (WITS). (2020). Data on Export, Import, Tariff, NTM. Retrieved April 11, 2020, from wits.worldbank.org website: https://wits.worldbank.org/

Nurul Zuriah. (2009). Metode Penelitian Sosial dan Pendidikan (ketiga). PT. bumi Aksara.

Thomas Oatley. (2004). International Political Economy:Interests and Institutions in The Global Economy.

Uber Silalahi. (2009). Metode Penelitian Sosial. Bandung: Refika Adhitama. 
Agus Sudarsono. (2013). Globalisasi Ekonomi dan Implikasinya Terhadap Negara Sedang Berkembang (pp. 4-18). pp. 4-18. Retrieved from http://staffnew.uny.ac.id/upload/130891326/lainlain/GLOBALISASI+EKONOMI+DAN+IM PLIKASINYA+TERHADAP+NEGARA+BERKEMBANG.pdf

Herlan Firmansyah dan Endang Hendra. (2015). Implikasi Globalisasi Ekonomi dan Perdagangan Bebas Terhadap Stabilitas nilai Rupiah. Asy-Syari'ah, 17(1), 46-54. https://doi.org/10.1145/3132847.3132886

Kurecic, P., \& Kokotovic, F. (2017). The Relevance of Political Stability on FDI: A VAR Analysis and ARDL Models for Selected Small, Developed, and Instability Threatened Economies. (2009). https://doi.org/10.3390/economies5030022

Masniadi, R. (2012). Analisis Pengaruh Jumlah Penduduk, Tabungan, Dan Investasi Terhadap Tingkat Pendapatan Per Kapita Indonesia. Jurnal Ekonomi Pembangunan, 10(1), 69. Retrieved from http://ejournal.umm.ac.id/index.php/jep/article/view/3718/4188

Rolo, M. N. M. C. (2017). Analysis Of The Foreign Direct investment: The Case of Portugal. (September), 1-97. Retrieved from https://repositorio.iscteiul.pt/bitstream/10071/15784/1/maria_cabral_rolo_diss_mestrado.pdf

Santoso. (2011). Pengaruh Hutang Luar Negeri, Kurs Dan Fdi Terhadap Produk Domestik Bruto Di Indonesia Tahun 1990-2008 Dengan Pendekatan Error Correction Model. Retrieved from http://e-journal.uajy.ac.id/1590/3/2EP15976.pdf

Septanto, H. (2016). Ekonomi Kreatif dan Inovatif Berbasis TIK ala Gojek dan Grabbike. Bina Insani ICT Journal, 3(1), 213-219. Retrieved from http://ejournalbinainsani.ac.id/index.php/BIICT/article/view/818/661

Subekti, M. M., \& Worokinasih, S. (2018). Pengaruh Tingkat Inflasi, Tingkat Pertumbuhan Ekonomi, Tingkat Suku Bunga, Dan Kurs Terhadap Keputusan Foreign Direct Investment (Studi Pada Negara China, Hongkong, Singapura, India, dan Indonesia Periode 2002- 2016). Jurnal Administrasi Bisnis (JAB)1, 61(2), 187-193. Retrieved from http://administrasibisnis.studentjournal.ub.ac.id/index.php/jab/article/viewFile/2588/2982

Sunardi, N. (2018). Kinerja Perusahan Pendekatan Du Pont System Terhadap Harga Dan Return Saham (Perusahaan yang tergabung dalam Industri Real Estate dan Properti yang terdaftar di Bursa Efek Indonesia Tahun 2011-2017). JIMF (Jurnal IImiah Manajemen Forkamma), 1(3).

Sunardi, N. (2019). Mekanisme Good Corporate Governance Terhadap Nilai Perusahaan Dengan Leverage Sebagai Variabel Intervening Pada Perusahaan Manufaktur Yang Terdaftar Di Bursa Efek Indonesia Tahun 2012-2018. JIMF (Jurnal IImiah Manajemen Forkamma), 2(3).

Sunardi, N. (2018). Analisis Economic Value Added (Eva), Financial Value Added (FVA) Dan Market Value Added (MVA) Dengan Time Series Approach Sebagai Alat Penilaian Kinerja Keuangan (Studi Pada Industri Konstruksi (BUMN) di Indonesia Yang Listing di BEI Tahun 2013-2017). Jurnal SEKURITAS (Saham, Ekonomi, Keuangan dan Investasi), 2(1).

Suliswanto, M. S. W. (2016). Tingkat Keterbukaan Ekonomi Di Negara Asean-5. Neo-Bis, 10(1), 33-48. https://doi.org/10.21107/NBS.V1011.1582

Walter, A., \& Sen, G. (2008). Analyzing the global political economy. In Analyzing the Global Political Economy. https://doi.org/10.1111/j.1475-4932.2009.00601.x 